International Journal of Management and Sustainability

2019 Vol. 8, No. 1, pp. 48-60

$\operatorname{ISSN}(e):$ 2306-0662

$\operatorname{ISSN}(p): 2306-9856$

DOI: $10.18488 /$ journal.1 1.2019.81.48.60

(C) 2019 Conscientia Beam. All Rights Reserved.

check for
updates

\title{
DEMOGRAPHIC FACTORS INFLUENCE ON THE TENDENCY TO BECOME ENTREPRENEUR: ESTIMATING THE ANTECEDENTS AND CONSEQUENCES OF ENTREPRENEURIAL TENDENCY
}

(D) Mohammad
Rashed Hasan Polas ${ }^{1+}$
(D) Amitab
Bhattacharjee $^{2}$
(iD) Valliappan Raju
(D) Mohammad Imtiaz
Hossain $^{4}$

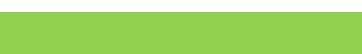

Article History

Received: 22 October 2018 Revised: 6 December 2018 Accepted: 12 February 2019 Published: 2 April 2019

\section{Keywords}

Entrepreneur

Nationality

Religion

Child position

Gender and business

environment.

\author{
${ }^{\prime}$ PhD Researcher, Center for Post Graduate Studies, Limkokwing University \\ of Creative Technology, Malaysia. \\ Email: rashedhasanpalash@gmail.com \\ ${ }^{2}$ Independent Researcher, Nihon Wellness Sports University, Itabashi, Tokyo, \\ Japan. \\ Email:bhattacharjee.ar@gmail.com \\ ${ }^{3}$ Associate Professor, Center for Post Graduate Studies, Limkokwing \\ University of Creative Technology, Malaysia. \\ Email:valliappanoos@gmail.com \\ ${ }^{\text {}}$ Post Graduate Student, Faculty of Economics and Management, Universiti \\ Putra Malaysia. \\ Email:_mtiazhossain677@gmail.com
}

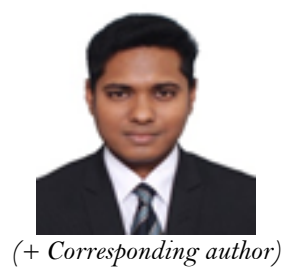

ABSTRACT

The essence of this study deals with identifying the major demographic factors for the tendency to become an entrepreneur. Our survey data from 132 randomly selected respondents were used to investigating the factors for the tendency to become an entrepreneur. In this study, a quantitative method was used to improve research strength. This study identified some major factors which increase an individual's entrepreneurial tendency. The study found a significant relationship between educational degree specialization, nationality, gender, entrepreneur parent, child position, marital status, age towards the tendency to become an entrepreneur. Moreover, the study further didn't find any relationship between performance (CGPA), religion and abroad experience towards the tendency to become an entrepreneur than earlier findings. Moreover, the entrepreneur is the combination of risk and willingness to find success but it's not easy to be like that because of both effects of internal and external business environments and therefore this study is conducted to identify core factors, which may influence on the willingness of an individual for being an entrepreneur. It is truly noticed the business-oriented scope for female compared to male in the same region that supports the other major factor called nationality. However, this study is conducted over postgraduate students studying in Malaysia that may focus a limitation but its overall results will fairly demonstration tendency to become an entrepreneur based on the international business environment perspective.

Contribution/Originality: This study is one of the very few studies which have investigated the relationship between demographic factors of students and their tendency to become an entrepreneur through empirical analysis and analyses whether students become influenced to become an entrepreneur through the core demographic factors.

\section{INTRODUCTION}

Since long before, entrepreneurship is a common phenomenon around the world. It has a huge effect on GDP economic growth. University students, academics, economists, policymakers all are talking about this topic. To raise the awareness about the importance of entrepreneurship, various TV shows, training, workshops, seminars are being held across the country every year for society and individual development (Fayolle, 2013; Solesvik et al., 
2014). It is stated that for the development of any economy entrepreneurship has a key role. To sustain the country's competitiveness, entrepreneurship plays an important role (Basu, 2014; Pilkova et al., 2014). Entrepreneurship creates wealth and produces job opportunities (Ghazali et al., 2013; Espíritu-Olmos and SastreCastillo, 2015; Moses et al., 2016).

The major objective of this study is to identify the major demographic factors for the tendency to become entrepreneur. Many researchers indicated student's tendency to become entrepreneur in their study. Ayodele (2013) conducted a study among some Nigerian adolescents to figure out the entrepreneurial tendency. He investigated the relationship between sex, socioeconomic status, age, locus of control, entrepreneurial self-efficacy and entrepreneurial intentions. Furthermore, Koe et al. (2012) showed in their study about the determinants of Entrepreneurial Intention among the Millennial Generation. They figured in their study by extending Ajzen (1991) theory of planned behavior (TPB) to study entrepreneurial intention among the millennial generation. Specifically, they mentioned to make the relationship between knowledge, experience and ties, attitude, social norm, perceived behavioural control and personality traits towards entrepreneurial tendency. After that, Ismail et al. (2009) illustrated in their study about entrepreneurial Intention among Malaysian Undergraduates where they explored the relationship between the Big-Five personality factors, contextual factors and entrepreneurial intention. Adding most importantly, Rasli et al. (2013) assumed in their study about factors affecting entrepreneurial intention among Graduate Students in Malaysia. They investigated the relationship between work experience, vicarious experience, general attitude, an image of entrepreneurship and other demographic variables towards entrepreneurial tendency. Likewise, many researchers conducted huge studies to know about the entrepreneurial tendency among students, but study investigating demographic factors are not enough for the understanding of entrepreneurial tendency. Moreover, in doing so, we tried to figure out the relationship between demographic factors and tendency to become entrepreneur and how demographic factors affect the students' entrepreneurial tendency.

\section{REVIEW OF LITERATURE}

There are some factors connected with the tendency of people to engage in entrepreneurial activity. Among them, demographic factors are the most significant. These factors are strategically important for the tendency to become an entrepreneur.

\subsection{Demographic Factors}

Different researches have been stated that demographic characteristics and family background influence on individuals to become entrepreneur (Remeikiene et al., 2013; Atef and Al-Balushi, 2015). However, there is a significant relationship between demographic characteristics and tendency to be entrepreneur who contributes to entrepreneurial detour (Espíritu-Olmos and Sastre-Castillo, 2015; Ismail et al., 2015). Besides, some other researchers also mentioned that there is a significant relationship between education level, age (Cumberland et al., 2015) marital status (Sauer and Wilson, 2016) with a tendency to become entrepreneur. Education level affects the tendency of people to engage in entrepreneurial activities (Crawford et al., 2015; Björklund and Krueger, 2016; Koskimaki, 2018). If people become highly educated, they are more probably to engage in entrepreneurial activity. Because, education helps to learn the new business opportunities (Lindquist et al., 2015) and information and skills acquired from education which raises the expected returns to entrepreneurial activity (Kuratko et al., 2015). In this way, education affects the tendency of people to engage in entrepreneurship.

Nevertheless, people want to be boss my own self. They don't prefer job under others' domination. They want to be self-employed (Llopis et al., 2015). A person engages in the start-up business of the desire for independence. Usually, people engage in start-up business because they want to be boss in their own kingdom and want to be free. They don't like to work with a huge group of the population with others' supervision (Bergmann et al., 2016). Every individual prefers self-employed. They think that it is one of the best career paths for them. They also think that 
being an entrepreneur they can execute their personal goals, get financial rewards and innovate own ideas (Palalic et al., 2017).

Moreover, people sometimes start a business because of heritability. Sometimes family business also influences to become an entrepreneur. It is told that heritability is more important even after taking into realization the influence of age, income, education, marital status, race, and immigrant status (Lindquist et al., 2015). Previous research states that women have more probability to become entrepreneur than men because of higher heritability (Shane and Nicolaou, 2015).

\subsection{The tendency to Become Entrepreneur}

Moreover, entrepreneurial tendency stated that people's willingness to act entrepreneurial behavior and tend to entrepreneurial actions, being self-employed and build new venture (Phuong and Hieu, 2015; Oguntimehin and Olaniran, 2017). Individuals must have a tendency to become an entrepreneur. Although they have a probability to become an entrepreneur, they don't participate in any entrepreneurship action (Mohamad et al., 2015). Liñán and Fayolle (2015) suggested that entrepreneurial tendency mentions to one person's mentality which indicates establishing a new business, improving the new business concept, adding new value within an existing business. Entrepreneurial tendency is very important for newly establishment business and it has a positive influence on the business's success and growth.

Scholars provided evidence that entrepreneurial tendency is a valid factor. Many studies show that entrepreneurial tendency gives significant insights for the researcher to realize entrepreneurial process and predict entrepreneurial actions in the best ways through identifying antecedents of entrepreneurial tendency (Yousaf et al., 2015; Ibrahim and Mas'ud, 2016; Farrukh et al., 2017; Gelaidan and Abdullateef, 2017). Generally, no individuals start its a reflection of anything, they start it intentionally. They don't start it accidentally (Santos et al., 2016; Nabi et al., 2017). They also proposed that entrepreneurial tendency assists in describing the reasons why potential entrepreneur emphasize to begin their own venture when they think about the type of business. They also stated that entrepreneurs get facilities from a better thought of their own tendency. There are some factors which drive them to take their decisions to decide about an entrepreneurial career. They further think about how thoughts can be turned into reality (Fayolle et al., 2014).

Many studies stated that university students are given proper training as an initial formulation to access into the business world. Their tendency determines whether they will be employees or entrepreneurs after their studies. The tendency is the predicted results conducted by some actions (Sandri, 2016). Many researchers indicated the student's tendency to become an entrepreneur. The study mentioned that $30.4 \%$ of the respondents have the tendency to become entrepreneurs. Most of these studies have done in developed countries at the college level, however less attention by scholars to understand these relationships at university level specially the post graduate business students in developing countries such as Malaysia. Entrepreneurial tendency has vindicated to be the initial predictor of future entrepreneurial actions (Shinnar et al., 2014; Zahra et al., 2014; Manik and Sidharta, 2016). In entrepreneurship study, seeking what are the factors behind the entrepreneurial tendency is very crucial. In total fewer women bend to begin their own business than men because of the influence of gender on entrepreneurship.

For beginning any new business, multi-layered procedures have to be completed for taking the decision (Tiwari et al., 2017). Many studies identified some variables which are the major antecedents for the tendency to become entrepreneur. Demographic factors such as education, age, parent's profession, gender, nationality are considered most crucial factors of entrepreneurial intension (Reuijl, 2013). Similar study indicates that the probability of decrease in entrepreneurial action in those countries which face population maturity.

Beginning a new business is an intentional activity including revolved efforts to practice control over the procedures in case to gain the expected results (McDonald et al., 2015; Mandl et al., 2016). There is a relationship between age and tendency to become entrepreneur. Business succeeds at highest level at early age and decline after 
that (Reuijl, 2013). The similar study states that when age rises, individuals loses willingness to give time to actions which provide returns over time such a beginning any business. People between 25 and 34 years old have the most probability to become entrepreneur (Leutner et al., 2014).

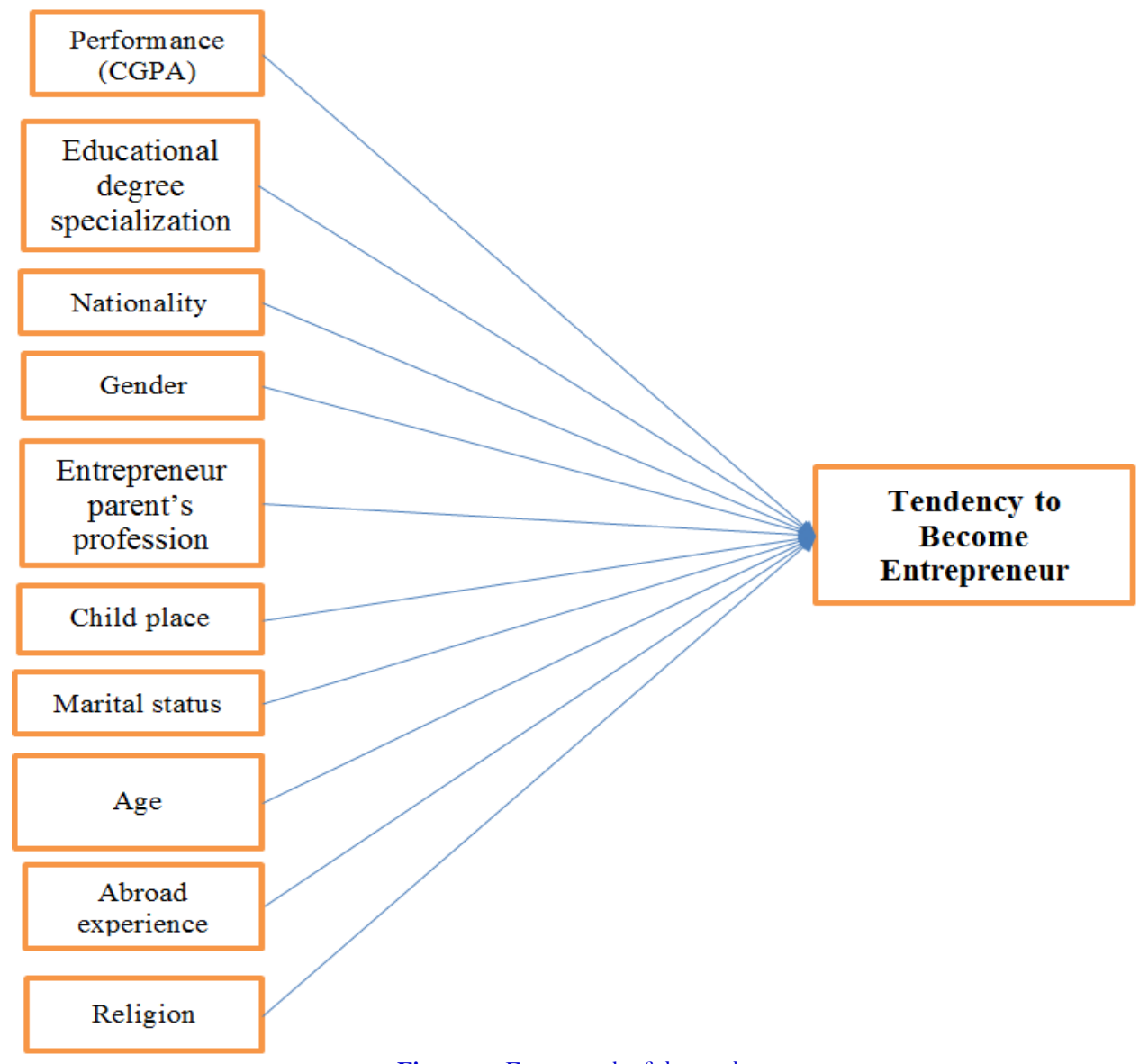

Figure-1. Framework of the study.

Figure 1 indicates that each and every variable in the framework influences ( namely performance as CGPA, educational degree specialization, nationality, gender, entrepreneur parent's profession, child place, marital status, age, abroad experience and religion) on the entrepreneurial tendency of individual especially students. Later, we investigated how these variables affect entrepreneurial tendency.

H1: There is a significant relationship between student's CGPA (performance) and their tendency to become entrepreneur.

H2: There is a significant relationship between educational degree specialization and tendency to become entrepreneur.

H3: There is a significant relationship between nationality and tendency to become entrepreneur.

H4: There is a significant relationship between Gender and tendency to become entrepreneur.

H5: There is a significant relationship between Entrepreneur parent's profession and tendency to become entrepreneur.

H6: There is a significant relationship between Child Place and tendency to become entrepreneur.

H7: There is a significant relationship between marital status and tendency to become entrepreneur.

H8: There is a significant relationship between Age and tendency to become entrepreneur.

H9: There is a significant relationship between Religion and tendency to become entrepreneur.

H10: There is a significant relationship between abroad experience and tendency to become entrepreneur. 


\section{RESEARCH METHODOLOGY}

The survey was conducted among the Post-graduate students of Limkokwing University of Creative Technology, CyberJaya, Malaysia. The questionnaire consists of fifteen questions adopted from (Leong, 2008; Liñán and Chen, 2009). Five-point Likert scale (with $1=$ strongly disagree, $2=$ disagree, $3=$ neutral, $4=$ agree, $5=$ strongly agree) is used as measurement range for every statement. The ten questions have been used as both close ended and open-ended questions. In this study, Pearson's Correlation and hierarchical linear regression has been applied to figure out the result. SPSS software has been applied to analyse the collected primary data.

The population of this study consists of all the postgraduate students of Limkokwing University of Creative Technology, CyberJaya, Malaysia. Firstly, the questionnaire was provided to the students individually. The researchers generally handed over the questionnaire to those students who were interested to contribute in the study. According to Krejcie and Morgan (1970) a sample size of 132 respondents has been considered, where total number of population is two hundred (in number 200). Followed by the sample size table of Krejcie and Morgan (1970) one hundred thirty-two respondents (sharply 132) are the sample size of this research.

Furthermore, by estimating the variance inflation factors (VIF) for all variables of the study (Tabachnick et al., 2007) we investigated the multicollinearity problem. Here, the highest VIF was 1.226, which is relatively below the conventional level of 5. For this reason, collinearity is not a significant problem in this study. After that, we applied a time trend extrapolation test (Armstrong and Overton, 1977) to know the non-response bias. In doing so, there is no conventional proof that our data are subject to non-response bias. Finally, prior to the distribution of survey, we reorganized and assorted the items which were envisioned to measure a certain variable with the items that were intended to measure other variables (Jahanshahi et al., 2017; Polas et al., 2018).

\subsection{Variable Measurement}

\subsubsection{Independent Variable}

There are ten independent variables namely CGPA (close ended), Educational degree specialization (close ended), Nationality (open ended), Gender (close Ended), Entrepreneur parent's profession (open ended), Child Place (close ended), Marital status (close ended), Age (open ended), Religion (close ended), Abroad Experience (open ended).

\subsubsection{Dependent Variable}

In this study, Tendency to become entrepreneur (TBE) is the only one dependent variable. Five statements or questions are used as items of TBE which was adopted from (Leong, 2008; Liñán and Chen, 2009) (namely; I prefer to be an entrepreneur rather than to be an employee in a company, My professional goal is to establish my own business, I'm determined to create a firm in the future, I will make every effort to manage my own business, I have a very serious thought in starting my own business).The five point Likert-scale is followed to measure each item with ( $1=$ Strongly Disagree, $2=$ Disagree, $3=$ Neutral, $4=$ Agree, $5=$ Strongly Agree). The minimum acceptance level of reliability is 0.7 , the reliability of dependent variable is found as 0.732 or $73.2 \%$ according to the Cronbach's Alpha model of reliability tested on SPSS.

\section{RESULTS OF STUDY}

Descriptive statistics and correlation Table 1 shows that fluxing correlation between independent variables namely CGPA, education specialization, nationality, gender, entrepreneurship of parents, child position, marital status, age, abroad experiences, religion and dependent variable stated as intension to be an entrepreneur. As seen that there were total six independent variables significantly correlated with dependent variable at different level, whereas rest of the independent variables were left out of significant level. Child position was correlated with 
dependent variable, which was significant at the $0.268^{* *}$ level. On the other hand, academic CGPA of a person was negatively correlated with dependent variable.

Adding more importantly, gender was found as highest major influential factor of IVs, which was positively correlated with tendency to become an entrepreneur or TBE, the significant of correlation was at the $0.293^{* *}$ level. Like that nationality and age were significantly correlated with TBE at the $0.235^{* *} \& 0.185^{* *}$ level respectively. Profession of entrepreneur's parent was also significantly correlated with dependent variable namely TBE at the $0.192^{* *}$ level. There was one more independent variable (Marital Status) correlated with TBE at the $0.197^{* *}$ level.

In this study, the exploratory factor analysis (EFA) illustrated that ensuing the theory of (Kaiser Meyer Olkin $(\mathrm{KMO})=0.668$; Bartlett's $=0.000$ where all the items were gathered and our collected data were best suit to investigate the research objectives. Here, we applied the confirmatory factor analysis (CFA) to figure out convergent validity resulting in the suggestions of Anderson and Gerbing (1988). After that, we want to know whether all scale items applied in this study put on their hypothesized construct factors at the level of significant. The result of this study delivered the proof of convergent validity for our measurement scales. We used hierarchical linear regression to examine the hypotheses of the study.

According to the Table 2, the estimated regression equation for the Tendency to Become Entrepreneur (TBE) is:

$\mathrm{TBE}=2.470+(0.061) \mathrm{CGPA}+(0.332) \mathrm{EDU} . \mathrm{SPECI}+0.437 \mathrm{NATIONALITY}+0.499$ GENDER $+0.513 \mathrm{ENT} . \mathrm{PAR}+0$ .339 CHI.POSI+0.443M.STATUS+0.564AGE+(-0.088)ABR.EXP+(-0.052)RELIGION

Hypothesis 1, which deals with the direct and positive relationship between cumulative grade point average and tendency to become entrepreneur. As can be inferred from Table 2, the relationship between cumulative grade point average and tendency to become entrepreneur is not positive and statistically significant $(\beta=-0.061, p>0.05)$. Thus, hypothesis 1 isn't supported. This means that higher cumulative grade point average, does not increase tendency of students to become an entrepreneur in future.

Hypothesis 2, which deals with the direct and positive relationship between educational specialization and tendency to become entrepreneur. As can be inferred from Table 2, the relationship between educational specialization and tendency to become entrepreneur is positive and statistically significant $\left(\beta=0.332^{* *}, p<0.01\right)$. Thus, hypothesis 2 is supported. This means that higher educational specialization increases tendency of students to become an entrepreneur in future.

Hypothesis 3, which deals with the direct and positive relationship between nationality and tendency to become entrepreneur. As can be inferred from Table 2 , the relationship between nationality and tendency to become entrepreneur is positive and statistically significant $\left(\beta=0.437^{* *}, \mathrm{p}<0.01\right)$. Thus, hypothesis 3 was fully supported. This means any increase or decrease in nationality cause increase or decrease in tendency of students to become an entrepreneur in future.

Hypothesis 4, which deals with the direct and positive relationship between gender and tendency to become entrepreneur. As can be inferred from Table 2, the relationship between gender and tendency to become entrepreneur is positive and statistically significant $\left(\beta=0.499^{* *}, p<0.01\right)$. Thus, hypothesis 4 was fully supported. This means any increase or decrease in gender cause increase or decrease in tendency of students to become an entrepreneur in future.

Hypothesis 5, which deals with the direct and positive relationship between profession of entrepreneur's parent and tendency to become entrepreneur. As can be inferred from Table 2, the relationship between profession of entrepreneur's parent and tendency to become entrepreneur is positive and statistically significant ( $\beta=0.513^{* *}, \mathrm{p}$ $<0.01)$. Thus, hypothesis 5 is supported. This means any increase or decrease in profession of entrepreneur's parent increases or decreases in tendency of students to become an entrepreneur in future. 


\begin{tabular}{|c|c|c|c|c|c|c|c|c|c|c|c|c|c|c|}
\hline SL. NO. & Name of Variables & Mean & STD. & 1 & 2 & 3 & 4 & 5 & 6 & 7 & 8 & 9 & 10 & 11 \\
\hline 1 & CGPA (Performance) & 2.7197 & 0.1073 & 1 & & & & & & & & & & \\
\hline 2 & $\begin{array}{ll}\text { Educational } & \text { Degree } \\
\text { Specialization } & \\
\end{array}$ & 1.6212 & 0.8783 & 0.125 & 1 & & & & & & & & & \\
\hline 3 & Nationality & 6.9242 & 4.7833 & 0.117 & -0.005 & 1 & & & & & & & & \\
\hline 4 & Gender & 6.9242 & 0.4783 & 0.128 & -0.01 & -0.005 & 1 & & & & & & & \\
\hline 5 & Entrepreneur Parent & 1.303 & 0.4613 & 0.138 & -0.054 & -0.021 & $.694^{* *}$ & 1 & & & & & & \\
\hline 6 & Child Place & 2.25 & 1.4795 & 0.062 & 0.079 & 0.047 & 0.016 & 0.101 & 1 & & & & & \\
\hline 7 & Marital Status & 1.3409 & 0.5362 & $.188^{*}$ & -0.064 & 0.019 & $.694^{* * *}$ & $.906^{* *}$ & 0.161 & 1 & & & & \\
\hline 8 & Age & 28.849 & 2.482 & -0.024 & 0.051 & 0.122 & $.186^{*}$ & 0.067 & $.177^{*}$ & 0.102 & 1 & & & \\
\hline 9 & Abroad Experience & 34.727 & 30.123 & -0.09 & -0.052 & -0.043 & 0.018 & -0.048 & -0.016 & -0.073 & 0.01 & 1 & & \\
\hline 10 & Religion & 2.2348 & 1.1843 & 0.155 & 0.071 & -0.167 & $.218^{*}$ & $.428^{* *}$ & -0.108 & $.294^{* * *}$ & -0.086 & -0.019 & 1 & \\
\hline 11 & $\begin{array}{lll}\text { Tendency } & \text { to } & \text { Become } \\
\text { Entrepreneur } & & \\
\end{array}$ & 3.9803 & 0.6713 & -0.005 & 0.003 & $.235^{* *}$ & $.293^{* *}$ & $.192^{*}$ & $.268^{* *}$ & $.197^{*}$ & $.185^{*}$ & 0.036 & 0.117 & 1 \\
\hline
\end{tabular}

Notes: ** Correlation is significant at the 0.01 level (2-tailed)
*Correlation is significant at the 0.05 level (2-tailed)

Table-2. Regression coefficient analysis.

\begin{tabular}{|c|c|c|c|c|c|c|c|c|c|c|c|}
\hline \multirow{2}{*}{$\begin{array}{l}\text { SL. } \\
\text { NO. }\end{array}$} & \multicolumn{11}{|c|}{ Tendency to Become Entrepreneur } \\
\hline & Name of Variables & Model1 & Model 2 & Model 3 & Model 4 & Model 5 & Model 6 & Model 7 & Model 8 & Model 9 & Model 10 \\
\hline 1 & CGPA (Performance) & -0.061 & & & & & & & & & \\
\hline 2 & $\begin{array}{ll}\text { Educational } & \text { degree } \\
\text { Specialization } & \end{array}$ & & $0.332 * *$ & & & & & & & & \\
\hline 3 & Nationality & & & $0.437 * *$ & & & & & & & \\
\hline 4 & Gender & & & & $0.499 * *$ & & & & & & \\
\hline 5 & Entrepreneur parent & & & & & $0.513^{* *}$ & & & & & \\
\hline 6 & Child place & & & & & & $0.339^{* * * *}$ & & & & \\
\hline 7 & Marital status & & & & & & & $0.443^{*}$ & & & \\
\hline 8 & Age & & & & & & & & $0.564 *$ & & \\
\hline 9 & Abroad experience & & & & & & & & & -0.088 & \\
\hline 10 & Religion & & & & & & & & & & -0.052 \\
\hline \multicolumn{2}{|c|}{$\mathrm{R}^{2}$} & 0.445 & 0.334 & 0.238 & 0.569 & 0.449 & 0.313 & 0.261 & 0.486 & 0.541 & 0.379 \\
\hline \multicolumn{2}{|c|}{ Adj. $R^{2}$} & 0.387 & 0.786 & 0.345 & 0.334 & 0.338 & 0.221 & 0.553 & 0.465 & 0.449 & 0.268 \\
\hline \multicolumn{2}{|c|}{$\mathrm{F}$} & $5.288^{* *}$ & 7.431 **** & 6.567 **** & $8.564 * * *$ & $7.456^{* * * *}$ & 4.337 *** & $3.651 * *$ & $3.159^{* *}$ & $6.369^{* * * *}$ & $6.866^{* * * *}$ \\
\hline
\end{tabular}


Hypothesis 6, which deals with the direct and positive relationship between child position and tendency to become entrepreneur. As can be inferred from Table 2, the relationship between child position and tendency to become entrepreneur is positive and statistically significant $\left(\beta=0.339^{* * *}, p<0.001\right)$. Thus, hypothesis 6 was fully supported. This means any increase or decrease in child position cause increase or decrease in tendency of students to become an entrepreneur in future.

Hypothesis 7, which deals with the direct and positive relationship between marital status and tendency to become entrepreneur. As can be inferred from Table 2, the relationship between marital status and tendency to become entrepreneur is positive and statistically significant $\left(\beta=0.443^{*}, p<0.05\right)$. Thus, hypothesis 7 is supported. This means any increase or decrease in child position increases or decreases in tendency of students to become an entrepreneur in future.

Hypothesis 8, which deals with the direct and positive relationship between age and tendency to become entrepreneur. As can be inferred from Table 2, the relationship between age and tendency to become entrepreneur is positive and statistically significant $(\beta=0.564 *, p<0.05)$. Thus, hypothesis 8 is supported. This means any increase or decrease in age increases or decreases in tendency of students to become an entrepreneur in future.

Hypothesis 9, which deals with the direct and positive relationship between abroad experiences and tendency to become entrepreneur. As can be inferred from Table 2 , the relationship between abroad experiences and tendency to become entrepreneur is not positive and statistically significant $(\beta=-0.088, p>0.05)$. Thus, hypothesis 9 wasn't supported. This means any increase or decrease in abroad experiences does not increase or decrease in tendency of students to become an entrepreneur in future.

Hypothesis 10, which deals with the direct and positive relationship between religion and tendency to become entrepreneur. As can be inferred from Table 2, the relationship between religion and tendency to become entrepreneur is not positive and statistically significant $(\beta=-0.052, p>0.05)$. Thus, hypothesis 10 wasn't supported. This means any increase or decrease in religion doesn't cause any increase or decrease in tendency of students to become an entrepreneur in future. 


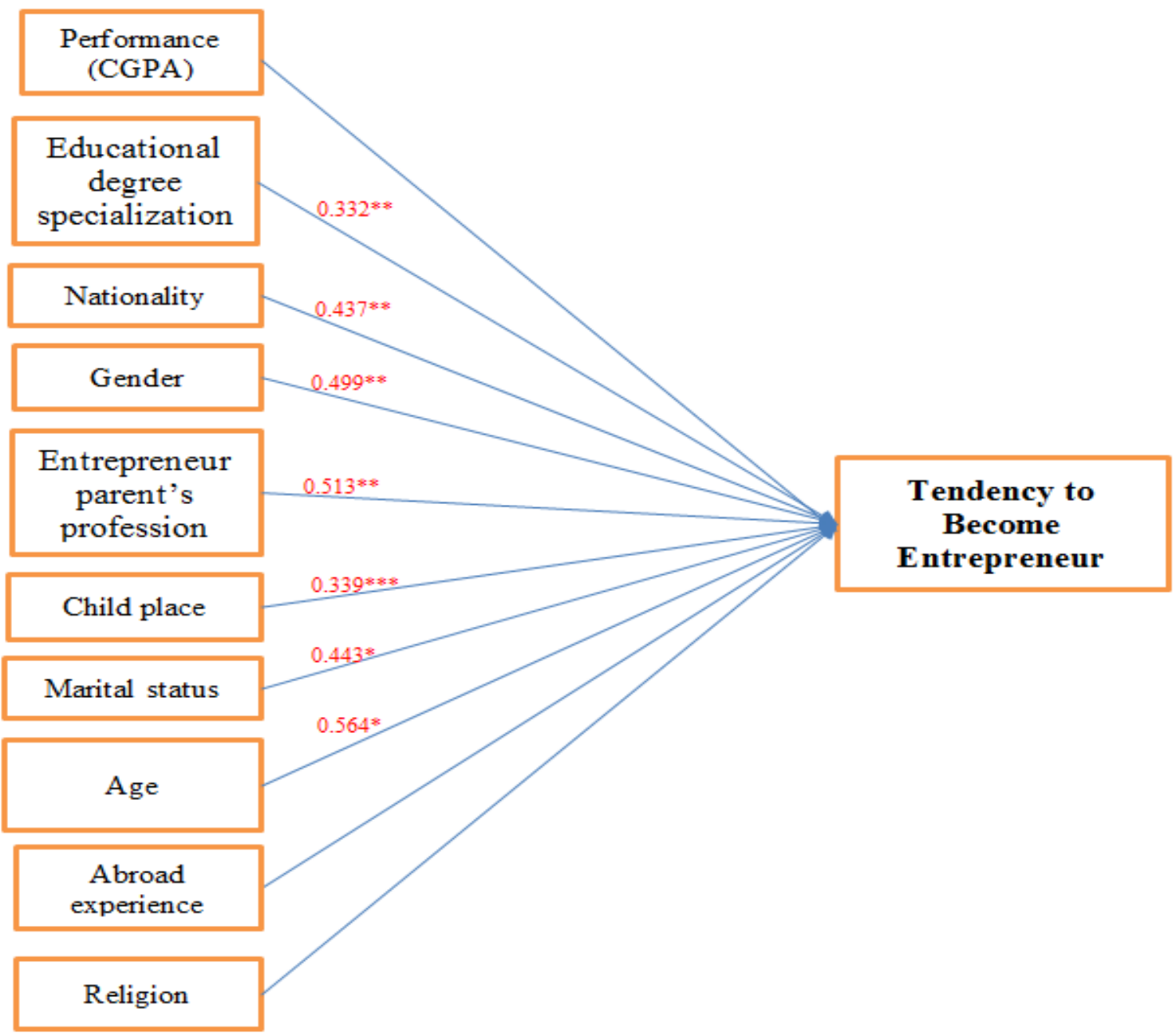

Figure-2. Significant model of the study.

Figure 2 demonstrates that educational degree specialization, nationality, gender, entrepreneur parent's profession, child place, marital status and age influence on the entrepreneurial tendency positively and significantly. Besides, CGPA, abroad experience and religion has no relationship with entrepreneurial tendency.

\section{CONCLUSION}

This study has made a clear scenario on the variables (CGPA, Educational Degree Specialization, nationality, gender, entrepreneur parent's profession, child position, marital status, age, abroad experience, Religion) which affect the students' entrepreneurial tendency. However, Managerial implications will raise the students' tendency to become entrepreneur. Limitations and recommendations will assist the future researchers to conduct their study properly. Socio-economies are changing. Entrepreneurships play a crucial role in developing the nation to alleviate the unemployment rate. Above all, researchers wish that this study will help the university students with essential knowledge how demographical factors influence an individual to become an entrepreneur.

By surveying 132 post graduate students at Cyber Jaya in Malaysia, the current paper found a significant relationship between educational degree specialization, nationality, gender, entrepreneur parent, child position, marital status, age towards tendency to become entrepreneur which indicates any increase in educational degree specialization, nationality, gender, entrepreneur parent, child position, marital status, age improve the entrepreneurial tendency of students. Moreover, the researchers further didn't find any relationship between performance (CGPA), religion and abroad experience towards tendency to become entrepreneur which denotes any increase in performance (CGPA), religion and abroad experience do not improve the entrepreneurial tendency of students. 


\subsection{Limitation and Recommendations for Future Studies}

In this study, only higher educational institute located in CyberJaya, Malaysia was selected to collect samples. Thus it has faced the limitation of location-feedbacks. Sample size of this study was only 132 respondents. So, the large sample size would be found different, is considered another limitation of this study. To conduct research on "The impact of entrepreneurial tendency in different countries", would be brought more accurate findings regarding this issue. Even another suggestion for new investigation is on "A relative study on the impact of entrepreneurial tendency between two regions in the same country". It will also help to identify the major factors behind the entrepreneurial intension in the different regions in a specific country.

Funding: This study received no specific financial support.

Competing Interests: The authors declare that they have no competing interests.

Contributors/Acknowledgement: Mohammad Rashed Hasan Polas coordinated the project and drafted this paper; Associate Prof. Dr. Valliappan Raju provided conceptual input and comments contributed to writing/revising main parts of the article; Amitab Bhattacharjee and Mohammad Imtiaz Hossain contributed to data collection, data analysis and formatting the paper. We sincerely thank and acknowledge the valuable time and cooperation given by Associate Professor Dr. Asghar Afshar Jahanshahi, Dept. Of Business Administration, Pontifical Catholic University of Peru.

\section{REFERENCES}

Ajzen, I., 1991. The theory of planned behavior. Organizational Behavior and Human Decision Processes, 50(2): $179-211$.

Anderson, J.C. and D.W. Gerbing, 1988. Structural equation modeling in practice: A review and recommended two-step approach. Psychological Bulletin, 103(3): 411-423.Available at: https://doi.org/10.1037//0033-2909.103.3.41 1.

Armstrong, J.S. and T.S. Overton, 1977. Estimating nonresponse bias in mail surveys. Journal of Marketing Research, 14(3): 396-402.Available at: https://doi.org/10.2307/3150783.

Atef, T.M. and M. Al-Balushi, 2015. Entrepreneurship as a means for restructuring employment patterns. Tourism and Hospitality Research, 15(2): 73-90.Available at: https://doi.org/10.1177/1467358414558082.

Ayodele, K.O., 2013. Demographics, entrepreneurial self-efficacy and locus of control as determinants of adolescents' entrepreneurial intention in Ogun State, Nigeria. European Journal of Business and Social Sciences, 1(12): 59-67.

Basu, R., 2014. Entrepreneurship education in India: A critical assessment and a proposed framework. Technology Innovation Management Review, 4(8): 5-10.Available at: https://doi.org/10.22215/timreview/817.

Bergmann, H., C. Hundt and R. Sternberg, 2016. What makes student entrepreneurs? On the relevance (and irrelevance) of the university and the regional context for student start-ups. Small Business Economics, 47(1): 53-76.Available at: https://doi.org/10.1007/s1 $1187-016-9700-6$.

Björklund, T.A. and N.F. Krueger, 2016. Generating resources through co-evolution of entrepreneurs and ecosystems. Journal of Enterprising Communities: People and Places in the Global Economy, 10(4): 477-498.Available at: https://doi.org/10.1 108/jec-10-2016-063.

Crawford, G.C., H. Aguinis, B. Lichtenstein, P. Davidsson and B. McKelvey, 2015. Power law distributions in entrepreneurship: Implications for theory and research. Journal of Business Venturing, 30(5): 696-713.Available at: https://doi.org/10.1016/j.jbusvent.2015.01.001.

Cumberland, D.M., W.R. Meek and R. Germain, 2015. Entrepreneurial self-efficacy and firm performance in challenging environments: Evidence from the franchise context. Journal of Developmental Entrepreneurship, 20(01): 1550004.Available at: https://doi.org/10.1142/s 1084946715500041.

Espíritu-Olmos, R. and M.A. Sastre-Castillo, 2015. Personality traits versus work values: Comparing psychological theories on entrepreneurial intention. Journal of Business Research, 68(7): 1595-1598.Available at: https://doi.org/10.1016/j.jbusres.2015.02.001.

Farrukh, M., A.A. Khan, M. Shahid Khan, S. Ravan Ramzani and B.S.A. Soladoye, 2017. Entrepreneurial intentions: The role of family factors, personality traits and self-efficacy. World Journal of Entrepreneurship, Management and Sustainable Development, 13(4): 303-3 17.Available at: https://doi.org/10.1 108/wjemsd-03-2017-0018. 
Fayolle, A., 2013. Personal views on the future of entrepreneurship education. Entrepreneurship \& Regional Development, 25(78): 692-701.Available at: https://doi.org/10.1080/08985626.2013.821318.

Fayolle, A., F. Liñán and J.A. Moriano, 2014. Beyond entrepreneurial intentions: Values and motivations in entrepreneurship. International Entrepreneurship and Management Journal, 10(4): 679-689.Available at: https://doi.org/10.1007/s1 1365-014-0306-7.

Gelaidan, H.M. and A.O. Abdullateef, 2017. Entrepreneurial intentions of business students in Malaysia: The role of selfconfidence, educational and relation support. Journal of Small Business and Enterprise Development, 24(1): 5467.Available at: https://doi.org/10.1108/jsbed-06-2016-0078.

Ghazali, Z., N.A. Ibrahim and F.A. Zainol, 2013. Factors affecting entrepreneurial intention among UniSZA students. Asian Social Science, 9(1): 85.Available at: https://doi.org/10.5539/ass.v9n1p85.

Ibrahim, N. and A. Mas'ud, 2016. Moderating role of entrepreneurial orientation on the relationship between entrepreneurial skills, environmental factors and entrepreneurial intention: A PLS approach. Management Science Letters, 6(3): 225236.Available at: https://doi.org/10.5267/j.msl.2016.1.005.

Ismail, K., M.A. Anuar, W.W. Omar, A. Aziz, K. Seohod and C.S. Akhtar, 2015. Entrepreneurial intention, entrepreneurial orientation of faculty and students towards commercialization. Procedia-Social and Behavioral Sciences, 181: 349355.Available at: https://doi.org/10.1016/j.sbspro.2015.04.897.

Ismail, M., S.A. Khalid, M. Othman, H.K. Jusoff, N.A. Rahman, K.M. Kassim and R.S. Zain, 2009. Entrepreneurial intention among Malaysian undergraduates. International Journal of Business and Management, 4(10): 54-60.Available at: https://doi.org/10.5539/ijbm.v4n 10p54.

Jahanshahi, A.A., A. Brem and A. Bhattacharjee, 2017. Who takes more sustainability-oriented entrepreneurial actions? The role of entrepreneurs' values, beliefs and orientations. Sustainability, 9(10): 1636.Available at: https://doi.org/10.3390/su9101636.

Koe, W.-L., J.R. Sa’ari, I.A. Majid and K. Ismail, 2012. Determinants of entrepreneurial intention among millennial generation. Procedia-Social and Behavioral Sciences, 40: 197-208.Available at: https://doi.org/10.1016/j.sbspro.2012.03.181.

Koskimaki, L., 2018. From agrarian landlords to transnational entrepreneurs: Reconfiguring political influence in coastal South India. In Provincial Globalization in India. Routledge. pp: 158-177.

Krejcie, R.V. and D.W. Morgan, 1970. Determining sample size for research activities. Educational and Psychological Measurement, 30(3): 607-610.Available at: https://doi.org/10.1177/001316447003000308.

Kuratko, D.F., M.H. Morris and M. Schindehutte, 2015. Understanding the dynamics of entrepreneurship through framework approaches. Small Business Economics, 45(1): 1-13.Available at: https://doi.org/10.1007/s1 1187-015-9627-3.

Leong, C.K., 2008. Entrepreneurial intention: An empirical study among open University Malaysia students. Dessertation, Open University Malaysia Center for Graduate Studies.

Leutner, F., G. Ahmetoglu, R. Akhtar and T. Chamorro-Premuzic, 2014. The relationship between the entrepreneurial personality and the big five personality traits. Personality and Individual Differences, 63: 58-63.Available at: https://doi.org/10.1016/j.paid.2014.01.042.

Liñán, F. and Y.W. Chen, 2009. Development and cross-cultural application of a specific instrument to measure entrepreneurial intentions. Entrepreneurship Theory and Practice, 33(3): 593-617.Available at: https://doi.org/10.1111/j.15406520.2009.00318.x.

Liñán, F. and A. Fayolle, 2015. A systematic literature review on entrepreneurial intentions: Citation, thematic analyses, and research agenda. International Entrepreneurship and Management Journal, 11(4): 907-933.Available at: https://doi.org/10.1007/s11365-015-0356-5.

Lindquist, M.J., J. Sol and M. Van Praag, 2015. Why do entrepreneurial parents have entrepreneurial children? Journal of Labor Economics, 33(2): 269-296.Available at: https://doi.org/10.1086/678493. 
Llopis, J.A.S., J.M. Millán, R. Baptista, A. Burke, S.C. Parker and R. Thurik, 2015. Good times, bad times: Entrepreneurship and the business cycle. International Entrepreneurship and Management Journal, 11(2): 243-251.Available at: https://doi.org/10.1007/s11365-015-0361-8.

Mandl, C., E.S. Berger and A. Kuckertz, 2016. Do you plead guilty? Exploring entrepreneurs' sensemaking-behavior link after business failure. Journal of Business Venturing Insights, 5: 9-13.Available at: https://doi.org/10.1016/j.jbvi.2015.12.002.

Manik, E. and I. Sidharta, 2016. Entrepreneurial intention on studentpreneurs to become entrepreneur. International Review of Management and Marketing, 6(3): 625-630.

McDonald, S., B.C. Gan, S.S. Fraser, A. Oke and A.R. Anderson, 2015. A review of research methods in entrepreneurship 19852013. International Journal of Entrepreneurial Behavior \& Research, 21(3): 291-315.

Mohamad, N., H.-E. Lim, N. Yusof and J.-J. Soon, 2015. Estimating the effect of entrepreneur education on graduates' intention to be entrepreneurs. Education+ Training, 57(8/9): 874-890.Available at: https://doi.org/10.1 108/et-03-2014-0030.

Moses, C., A.M. Olokundun, H.O. Falola, A.S. Ibidunni, A.B. Amaihian and F. Inelo, 2016. A review of the challenges militating against women entrepreneurship in developing nations. Mediterranean Journal of Social Sciences, 7(1): 64-69.Available at: $10.5901 / \mathrm{mjss} .2016 . \mathrm{v} 7 \mathrm{n} 1 \mathrm{p} 64$.

Nabi, G., F. Liñán, A. Fayolle, N. Krueger and A. Walmsley, 2017. The impact of entrepreneurship education in higher education: A systematic review and research agenda. Academy of Management Learning \& Education, 16(2): 277299.Available at: https://doi.org/10.5465/amle.2015.0026.

Oguntimehin, Y.A. and O.O. Olaniran, 2017. The relationship between entrepreneurship education and students' entrepreneurial intentions in Ogun State-Owned Universities, Nigeria. British Journal of Education, 5(3): 9-20.

Palalic, R., V. Ramadani and L.P. Dana, 2017. Entrepreneurship in Bosnia and Herzegovina: Focus on gender. European Business Review, 29(4): 476-496.Available at: https://doi.org/10.1108/ebr-05-2016-0071.

Phuong, T.H. and T.T. Hieu, 2015. Predictors of entrepreneurial intentions of undergraduate students in Vietnam: An empirical study. International Journal of Academic Research in Business and Social Sciences, 5(8): 46-55.Available at: https://doi.org/10.6007/ijarbss/v5-i8/1759.

Pilkova, A., M. Holienka and J. Rehak, 2014. Senior entrepreneurship in the perspective of European entrepreneurial environment. Procedia Economics and Finance, 12: 523-532.Available at: https://doi.org/10.1016/s22125671(14)00375-x.

Polas, M.R.H., A.A. Jahanshahi and M.L. Rahman, 2018. Islamic branding as a tool for customer retention: Antecedents and consequences of Islamic brand loyalty. International Journal of Islamic Marketing and Branding, 3(1): 1-14.Available at: https://doi.org/10.1504/ijimb.2018.10012708.

Rasli, A., S.U.R. Khan, S. Malekifar and S. Jabeen, 2013. Factors affecting entrepreneurial intention among graduate students of Universiti Teknologi Malaysia. International Journal of Business and Social Science, 4(2): 182-188.

Remeikiene, R., G. Startiene and D. Dumciuviene, 2013. Explaining entrepreneurial intention of university students: The role of entrepreneurial education. In International Conference.

Reuijl, A., 2013. Determinants of latent entrepreneurship: The role of personality, occupation and unemployment benefit. Economics. Erasmus University. Available from http://hdl.handle.net/2105/13360.

Sandri, S., 2016. The need for entrepreneurial education in Jordan-an empirical investigation. Jordan Journal of Business Administration, 12(2): 417-435.Available at: https://doi.org/10.12816/0033357.

Santos, F.J., M.A. Roomi and F. Liñán, 2016. About gender differences and the social environment in the development of entrepreneurial intentions. Journal of Small Business Management, 54(1): 49-66.Available at: https://doi.org/10.1111/jsbm.12129.

Sauer, R.M. and T. Wilson, 2016. The rise of female entrepreneurs: New evidence on gender differences in liquidity constraints. European Economic Review, 86: 73-86.Available at: https://doi.org/10.1016/j.euroecorev.2015.10.010. 
Shane, S. and N. Nicolaou, 2015. Creative personality, opportunity recognition and the tendency to start businesses: A study of their genetic predispositions. Journal of Business Venturing, 30(3): 407-419.Available at: https://doi.org/10.1016/j.jbusvent.2014.04.001.

Shinnar, R.S., D.K. Hsu and B.C. Powell, 2014. Self-efficacy, entrepreneurial intentions, and gender: Assessing the impact of entrepreneurship education longitudinally. The International Journal of Management Education, 12(3): 561570.Available at: https://doi.org/10.1016/j.ijme.2014.09.005.

Solesvik, M., P. Westhead and H. Matlay, 2014. Cultural factors and entrepreneurial intention: The role of entrepreneurship education. Education+ Training, 56(8/9): 680-696.

Tabachnick, B.G., L.S. Fidell and J.B. Ullman, 2007. Using multivariate statistics. Boston, MA: Pearson, 5.

Tiwari, P., A.K. Bhat and J. Tikoria, 2017. An empirical analysis of the factors affecting social entrepreneurial intentions. Journal of Global Entrepreneurship Research, 7(1): 9.Available at: https://doi.org/10.1186/s40497-017-0067-1.

Yousaf, U., A. Shamim, H. Siddiqui and M. Raina, 2015. Studying the influence of entrepreneurial attributes, subjective norms and perceived desirability on entrepreneurial intentions. Journal of Entrepreneurship in Emerging Economies, 7(1): 23-34.Available at: https://doi.org/10.1108/jeee-03-2014-0005.

Zahra, S.A., M. Wright and S.G. Abdelgawad, 2014. Contextualization and the advancement of entrepreneurship research. International Small Business Journal, 32(5): 479-500.Available at: https://doi.org/10.1177/0266242613519807.

Views and opinions expressed in this article are the views and opinions of the author(s), International Journal of Management and Sustainability shall not be responsible or answerable for any loss, damage or liability etc. caused in relation to/arising out of the use of the content. 